\title{
EXPLORING THE IMPACT OF CELEBRITY ENDORSEMENTS ON THE ATTITUDES AND PURCHASING INTENTION IN INSTAGRAM
}

\author{
Ragil Asma Saputra ${ }^{* 1}$, Budi Suharjo ${ }^{* *}$, and Dadang Sukandar $\left.{ }^{* * *}\right)$ \\ *) School of Business, Bogor Agricultural University \\ Jl. Pajajaran, Bogor 16151 \\ **) Department of Mathematics, Faculty of Mathematics and Natural Sciences, Bogor Agricultural University \\ Jl. Meranti, Campus IPB Dramaga Bogor 16680 \\ ${ }^{* * *}$ Department of Nutrition Science, Faculty of Human Ecology, IPB University \\ Jl. Lingkar Akademik, Campus IPB Dramaga Bogor 16680
}

\begin{abstract}
The use of celebrities as endorser for companies is becoming a popular way for endorsement. This study aims to identify any differences on the impact of celebrity's credibility on attitudes towards endorsement (AAD), brand (AB) and purchase intention (PI) in single and multiple celebrity endorsement formats. Questionnaires were administered on a sample of 79 respondents. The data were analyzed using proportion test and Structural Equation Modeling analysis. The results suggest there were no significant differences in consumer perceptions and attitudes in single and multiple celebrity endorsements. Credible celebrities were proven to have direct effects on positive attitude towards endorsements and purchase intention, but the impacts were inconsistent in influcencing the attitude towards brands.
\end{abstract}

Keywords: celebrity credibility, celebrity endorsement, consumer attitudes, purchase intention

Abstrak: Penggunaan selebriti oleh perusahaan menjadi cara yang popular untuk suatu endorsement. Studi ini ingin mengetahui ada tidaknya perbedaan pengaruh kredibilitas selebriti pada sikap terhadap endorsement (AAD), merek (AB), dan minat pembelian (PI). Kuesioner diberikan pada 157 responden. Data dianalisis dengan menggunakan uji proporsi dan analisis Structural Equation Modeling. Hasilnya menunjukkan tidak ada perbedaan yang signifikan dalam persepsi dan sikap konsumen ketika mengevaluasi endorsement yang hanya menampilkan satu selebriti dan beberapa selebriti. Selebriti yang kredibel terbukti memiliki efek langsung pada sikap positif terhadap dukungan dan niat beli, tetapi pengaruhnya tidak konsisten pada sikap terhadap merek.

Kata kunci: kredibilitas selebriti, endorsement selebriti, sikap konsumen, minat pembelian

\footnotetext{
${ }^{1}$ Corresponding author:

Email: saputrar1985@gmail.com
} 


\section{INTRODUCTION}

Social media as one of the marketing tools is developing rapidly nowadays. Marketing through social media is a two-way communication between producers and consumers. The focus of marketing through this digital channel is to be able to connect with consumers, develop businesses, and create strong brands in the market. There are several social media that are used by marketing agents today, including Facebook, Instagram, Twitter, online blogs, and others. One of the most widely used social media platforms is Instagram (Raice and Spencer, 2012). Besides being used for social purposes, Instagram also has features for business people to start pioneering or developing a business.

One of advertising campaign which is very popular in Instagram nowadays is celebrity endorsement. A celebrity endorser is defined as "any individual who enjoys public recognition and who uses this recognition when they appear in the advertisement in front of the comsumers" and who often have distinctive attributes such as expertise, physical attractiveness and trustworthiness (Silvera and Austad, 2004). Celebrity endoserment is considered an effective promotional tool by marketers because it influences perception of product quality and uniqueness (Dean, 2001), advertising effectiveness, brand recognition, brand recall, purchase intentions (Chavda, 2010) and even purchase behavior compared to those campaign without celebrities involved (Mathur and Rangan, 1997; Goldsmith et al. 2000). On the other hand, the concerns of celebrity endorsement include celebrities who are more prominent than brands that are trying to be promoted or known as "overshadowing the brand" and whose image changes due to excessive exposure to celebrities who experience up and down popularity; threrefore, these have an impact on endorsement, and the costs incurred by the company are considerably expensive. The company is fully aware of the concerns described earlier, but it also realizes that celebrity endorsement is one of the effective promotional tools if done properly.

Multiple celebrity is defined as the use of two or more celebrities in an advertising campaign. Multiple celebrity endorsement occurs when several celebrities promote the same brand (Hsu and McDonald, 2002), either in one ad or in a series of different advertisements (Nam-Hyun, 2008). A large number of studies found that multiple celebrity endorsement can be advantageous for appealing to wider segments at the same time because it allows these celebrities to convey information to a different group of audiences, to reduce the boredom seeing the same celebrity from time to time, to boost ad and brand image, so that the purchase intention of consumer can be increased (Erdogan, 1999; Saleem, 2007).

This research was carried out to find out any differences on consumer's perception on credibility of celebrity and consumer's attitudes in two different formats of endorsements, i.e. single and multiple celebrity endorsements. Moreover, it also explored the impacts of celebrity credibility (CE) onattitudetowards endorsement (AAD), brands $(\mathrm{AB})$ and purchase intentions (PI) in single and multiple celebrity endorsement cases. This study was limited to the case of single celebrity endorsement and multiple celebrity endorsement on Instagram social media by choosing cosmetic brands, namely, Wardah as an experimental design.

\section{METHODS}

The data used in this study are primary and secondary data. Primary data was obtained directly from respondents through face-to-face quantitative interviews among 79 respondents, and was supported by secondary data collected from the literature studies of several theses, journal publications, dissertations, and research reports from several institutions.

Sampling was carried out by non-probability sampling, i.e. purposive sampling. In this study, the criteria for respondents interviewed included women, aged 18-34 years, owning smartphones, actively using Instagram social media, and following celebrity Instagram accounts.

Proportion test was used to know whether there were differences in perceptions and attitudes of consumers after evaluating 2 format endorsements. Structural Equation Modeling (SEM) is a method of data analysis used to show simultaneous relations between latent variables that cannot be observed with observation variables or also called indicators that represent the characteristics of latent variables (Indrayana et al. 2016). One of the estimation methods used in SEM is Unweighted Least Squares (ULS), and the nature of the estimator in the ULS method is consistent and does not require distribution assumptions from the observation variables. 
Related to the objectives to be achieved, the effectiveness of endorsement involving one celebrity or more than one celebrity was measured by consumer perceptions regarding the credibility of celebrities. Celebrity credibility itself is a variable formed from three dimensions including trust, expertise, and attractiveness. These three dimensions were latent variables that were measured through several indicators. The effectiveness of endorsement is not only assessed from consumer perceptions of celebrity credibility but also from its relationship with the attitudes of consumers and interest for buying products. The research framework can be seen in Figure 1 with the explanation of variables and indicators shown in Table 1.

\section{Hyphotesis}

Based on all the research objectives described, the hypotheses of this study included any differences in perceptions and attitudes of consumers towards endorsement with the format of single celebrity endorsement and multiple celebrity endorsement.

\section{Hyphotesis 1}

H0 : There is no difference in perceptions of celebrity credibility, consumer attitudes and purchase intention between single celebrity endorsement and multiple celebrity endorsement $(\mathrm{p} 1=\mathrm{p} 2)$.
H1 : There are differences in perceptions of celebrity credibility, consumer attitudes and purchase intention between single celebrity endorsement and multiple celebrity endorsement $(\mathrm{p} 1 \neq \mathrm{p} 2)$.

Hyphotesis 2

H0 : Celebrity credibility has a direct/indirect influence on consumer attitudes towards endorsement (both in the case of single celebrity endorsement and multiple celebrity endorsement).

H2 : Celebrity credibility does not have a direct/ indirect influence on consumer attitudes towards endorsement (both in the case of single celebrity endorsement and multiple celebrity endorsement).

Hyphotesis 3

H0 : Celebrity credibility has a direct/indirect influence on consumer attitudes towards brands (both in the case of single celebrity endorsement and multiple celebrity endorsement).

H3 : Celebrity credibility does not have a direct/ indirect influence on consumer attitudes towards the brand (both in the case of single celebrity endorsement and multiple celebrity endorsement).

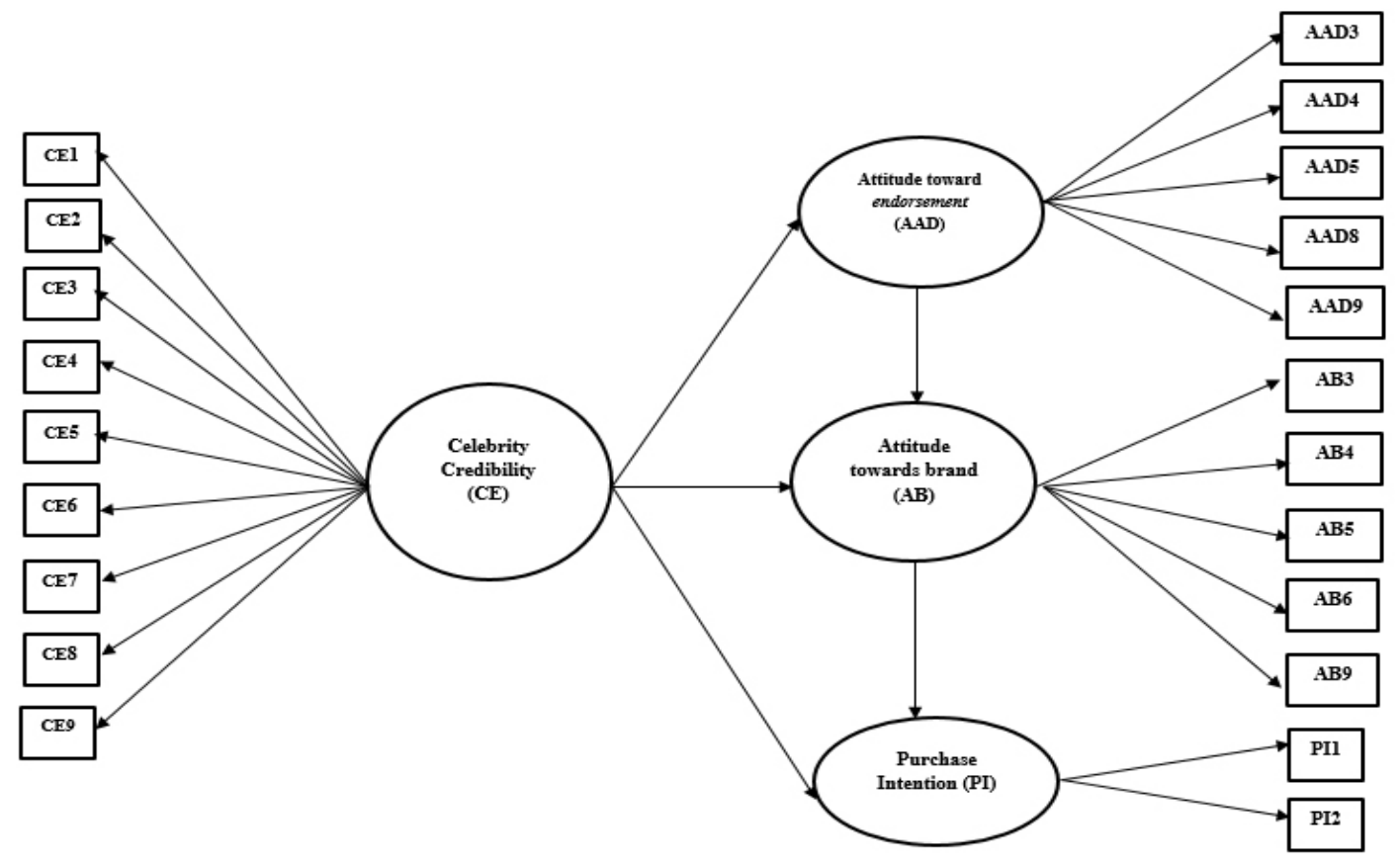

Figure 1. Research framework 
Table 1. Latent variables and indicators

\begin{tabular}{lcll}
\hline Latent variable & Code & Indicators & Reference \\
\hline Celebrity & CE1 & Smart & Ohanian (1990) \\
Credibility (CE) & CE2 & Suitable with product & \\
& CE3 & Informative & \\
& CE4 & Honest & \\
& CE5 & Trustworthy & \\
& CE6 & Honorable & \\
& CE7 & Attractive & Jatto (2014) \\
Attitudes & CE8 & Classy & \\
toward & CE9 & Elegant \\
endorsement & AAD3 & The ad was very creative & \\
(AAD) & AAD5 & The ad could be trusted & Wu and Wang \\
& AAD8 & The ad was unique/different & (2011) \\
Attitudes & AAD9 & The ad described quality products & \\
toward brand & AB3 & Wardah wasn't a brand that disappoint users & \\
(AB) & AB4 & Wardah was a brand that can be relied upon by users & Schiffman and \\
& AB5 & Wardah was a brand that can satisfy users & Kanuk (2010) \\
& AB6 & Wardah was a brand that can clean the user's facial skin & \\
Purchase & AB9 & Wardah was a brand that can nourish the user's skin & \\
Intention (PI) & PI1 & After viewing the ad, I will look for more information/details about the & product \\
& PI2 & After seeing the ad, I am interested in buying the product &
\end{tabular}

Hyphotesis 4

H0 : Celebrity credibility has a direct/indirect influence on the purchase intention (both in the case of single celebrity endorsement and multiple celebrity endorsement).

H4 : Celebrity credibility does not have a direct/ indirect influence on the purchase intention (both in the case of single celebrity endorsement and multiple celebrity endorsement).

\section{RESULTS}

The number of samples in this study were 79 respondents who evaluated Wardah's endorsement. The respondents were female aged 18-34 who had an Instagram account. Based on occupations, they were mostly housewives (38.0\%) and employees (38.0\%), followed by students $(19.0 \%)$ and entrepreneurs (5.0\%).

\section{Proportion Test Results}

By referring to the indicators of credibility of celebrities from Ohanian (1990), Table 3 concluded there were no significant differences on how consumers perceived credibility of Dewi Sandra and Raline Shah when both celebrites were displayed in single or multiple celebrity endorsement format. Consumers perceived the credibility of Dewi Sandra and Raline Shah as the same as displaying their figures individually or in pairs in one endorsement. This result is in line with the research conducted by Pughazhendi and Ravindran (2012) which stated that there were no significant differences in consumer attitudes both for advertisements featuring only one celebrity and some celebrities when evaluating products that belong to the high involvement category such as cosmetics.

The only indicator of attitude towards brands that showed significant differences in both endorsement formats was an indicator that stated "Wardah is not a brand that disappoints its users" when displaying both celebrities in the same Wardah endorsement. 
This finding revealed that differences in the number of celebrities featured in an advertisement could provide different reactions related to consumer attitudes toward advertising and brands, according to the theory and previous research by Sheth and Solanki (2015). In the context of purchase intention, the way of displaying celebrity in single and multiple celebrity formats did not show any any significant differences, and this result supported previous studies conducted by Pughazhendi and Ravindran (2012). The presence of Dewi Sandra alone in Wardah endorsement generated more positive intention to find more details of product than the case of herself displayed along with Raline Shah. When Raline Shah was displayed together with Dewi Sandra, purchasing interest of consumers was declining.

In Wardah endorsement, it was confirmed that there were no significant differences on the perceptions and attitudes of consumers when evaluating single and multiple celebrity endorsements. It can be concluded H0 was accepted. In the Table 2-5 showed negative scores indicating that consumers perceived and reacted more favourable when the endorsement showed multiple celebrities.

\section{Structural Equation Modeling}

Table 6 showed all the models for Wardah endorsements were fitted because they met all the overall goodness of fit criteria of the model. The measurement model explained the relationship between indicators and their latent variables. An indicator is said to be significant when it has a standardized loading factor (SLF) value of $\geq 0.50$ and t-value of $\geq 1.96$ (Hartono, 2008). Reliability or consistency of indicators reflecting latent variables can be seen from the values of Construct Reliabity $(C R) \geq 0.70$ and Variance Extracted $(V E) \geq 0.50$. When there are indicators in the model with a value of $\mathrm{VE} \leq$ 0.50 , it can still be said to be reliable in forming latent variables in the model if the CR value is still greater than 0.70 (Fornell and Larcker, 1981).

Table 2. Proportion test of celebrity credibility Wardah's endorsement

\begin{tabular}{lcc}
\hline Indicators of credibility & Z Dewi Sandra vs Multiple Celebrity & Z Raline Shah vs Multiple Celebrity \\
\hline Smart (CE1) & -0.87 & -1.12 \\
Suitable with product (CE2) & 0.00 & -0.73 \\
Informative (CE3) & -0.34 & 0.39 \\
Honest (CE4) & -0.27 & -1.44 \\
Trustworthy (CE5) & -1.05 & -1.05 \\
Honorable (CE6) & -0.87 & -1.58 \\
Attractive (CE7) & -0.45 & -1.72 \\
Classy (CE8) & -0.94 & -0.65 \\
Elegant (CE9) & -1.56 & -0.39 \\
\hline
\end{tabular}

*) significant at $\alpha=5 \%$

Table 3. Proportion test of attitude towards Wardah's endorsement

\begin{tabular}{lcc}
\hline Indicators of credibility & Z Dewi Sandra vs Multiple Celebrity & Z Raline Shah vs Multiple Celebrity \\
\hline The ad was very creative (AAD3) & -0.60 & -1.58 \\
The ad was very interesting (AAD4) & 0.70 & 1.22 \\
The ad could be trusted (AAD5) & 0.00 & -0.41 \\
The ad was unique / different (AAD8) & 0.54 & -0.17 \\
The ad described quality products (AAD9) & -0.73 & 0.56 \\
\hline
\end{tabular}

*) significant at $\alpha=5 \%$ 
Table 4. Proportion test of attitudes toward brand Wardah

\begin{tabular}{lcc}
\hline Indicators of credibility & Z Dewi Sandra vs Multiple Celebrity & Z Raline Shah vs Multiple Celebrity \\
\hline $\begin{array}{l}\text { Wardah wasn't a brand that disappoint } \\
\text { users (AB3) }\end{array}$ & -1.56 & $-2.44^{*}$ \\
$\begin{array}{l}\text { Wardah was a brand that can be relied } \\
\text { upon by users (AB4) }\end{array}$ & -1.80 & -1.03 \\
$\begin{array}{l}\text { Wardah was a brand that can satisfy } \\
\text { users (AB5) }\end{array}$ & -1.03 & -0.39 \\
$\begin{array}{l}\text { Wardah was a brand that can clean the } \\
\text { user's facial skin (AB6) }\end{array}$ & -0.45 & 0.00 \\
$\begin{array}{l}\text { Wardah was a brand that can nourish } \\
\text { the user's skin (AB9) }\end{array}$ & -0.83 & 0.00 \\
Honorable (CE6) & -0.87 & -1.58 \\
Attractive (CE7) & -0.45 & -1.72 \\
Classy (CE8) & -0.94 & -0.65 \\
Elegant (CE9) & -1.56 & -0.39 \\
\hline
\end{tabular}

*) significant at $\alpha=5 \%$

Table 5. Proportion test of purchase intention Wardah's product

\begin{tabular}{lcc}
\hline Indicators of credibility & Z Dewi Sandra vs Multiple Celebrity & Z Raline Shah vs Multiple Celebrity \\
\hline $\begin{array}{l}\text { After viewing the ad, I will look for } \\
\text { more information/details about the }\end{array}$ & 1.12 & 0.26 \\
product (PI1) & & -0.29 \\
$\begin{array}{l}\text { After seeing the ad, I am interested in } \\
\text { buying the product (PI2) }\end{array}$ & 0.31 & \\
\hline
\end{tabular}

*) significant at $\alpha=5 \%$

Table 6. Overall goodness of fit Wardah's Endorsement

\begin{tabular}{lcccc}
\hline GoF & Dewi Sandra & Raline Shah & Multiple celebrity & Reference \\
\hline p-value & 0.02 (Acceptable) & 1.00 (Good Fit) & 1.00 (Good Fit) & Schermelleh-Engel et al. 2003 \\
RMSEA & 0.05 (Good Fit) & 0.00 (Good Fit) & 0.00 (Good Fit) & McCallum et al. 1996 \\
\hline
\end{tabular}

*) significant at $\alpha=5 \%$

By paying attention to Figure 2, it can be concluded that all indicators in the model had a significant contribution in the formation of latent variables, and all indicators were reliable or consistent in forming latent variables. In Figure 3 regarding Wardah's endorsement model by the Raline Shah, all indicators were significant in measuring the latent variables, and it could be concluded that indicators were reliable in reflecting latent variables. In Wardah's endorsement featuring Dewi Sandra and Raline Shah simultaneously (Figure 4), all indicators contained in the model were able to reflect their latent variables well. There was a value of $\mathrm{VE} \leq 0.50$, and because the $\mathrm{CR}$ value was still greater than 0.70 , it concluded that all indicators for latent variable attitudes toward endorsement were reliable (Fornell and Larcker, 1981).
In the endorsement by Dewi Sandra, attractiveness (CE7-CE9) was the main criterion considered important in describing her as having a credible endorser, and the trustworthiness (CE4-CE6) criterion became the second most important point in describing Dewi Sandra as a credible endorser while the expertise of Dewi Sandra gave the smallest contribution in forming the credibility of an endorser. When both celebrities were displayed together, they could bring out a better perception of their expertise in promoting the Wardah brand. The details were shown in Table 7.

In Table 8, the existence of celebrities in each format provided different reactions in attitude towards the endorsement. In the single celebrity endorsement of Dewi Sandra and Raline Shah, it can be concluded that all indicators contributed with almost the same amount in reflecting consumer attitudes towards endorsement 
whereas in the multiple celebrity endorsement model, the contribution of AAD5 was believed to be the largest point in the process of forming latent attitude variables towards endorsement.

In Table 9, Dewi Sandra gave the biggest contribution on creating positive attitudes towards brands through the indicator that stated "Wardah is not a brand that disappoints users (AB3)" with a loading factor of 0.84 while in the endorsement that showed Raline herself, the biggest contribution to the formation of attitudes towards the brand was indicator that stated "Wardah is a brand that could be relied on by its users (AB4)" with a loading factor of 0.97 . In multiple celebrity format, both celebrities managed to bring up positive impression of the functional benefits of Wardah products that can nourish the skin of its users

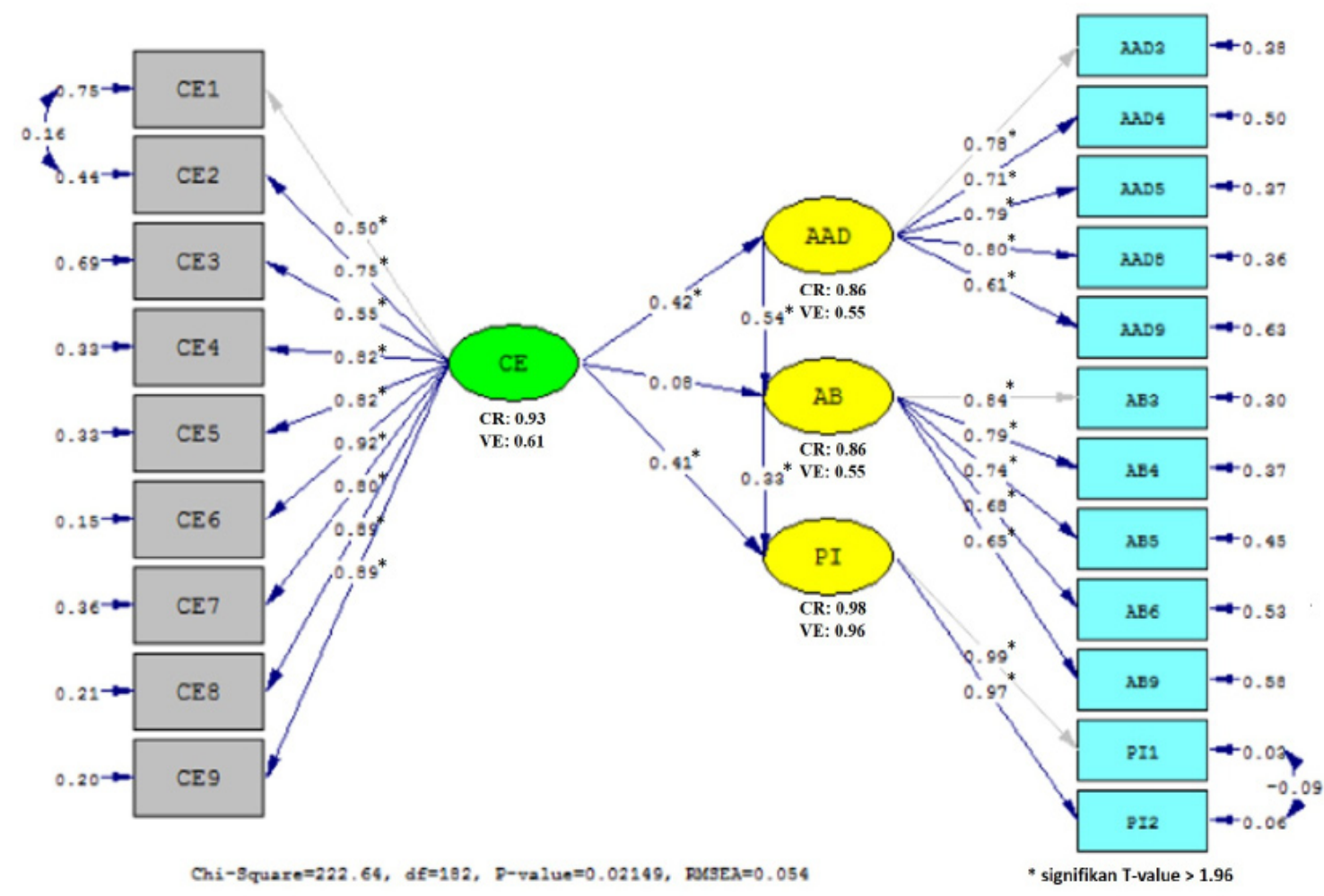

Figure 2. Structural equation modeling of Dewi Sandra

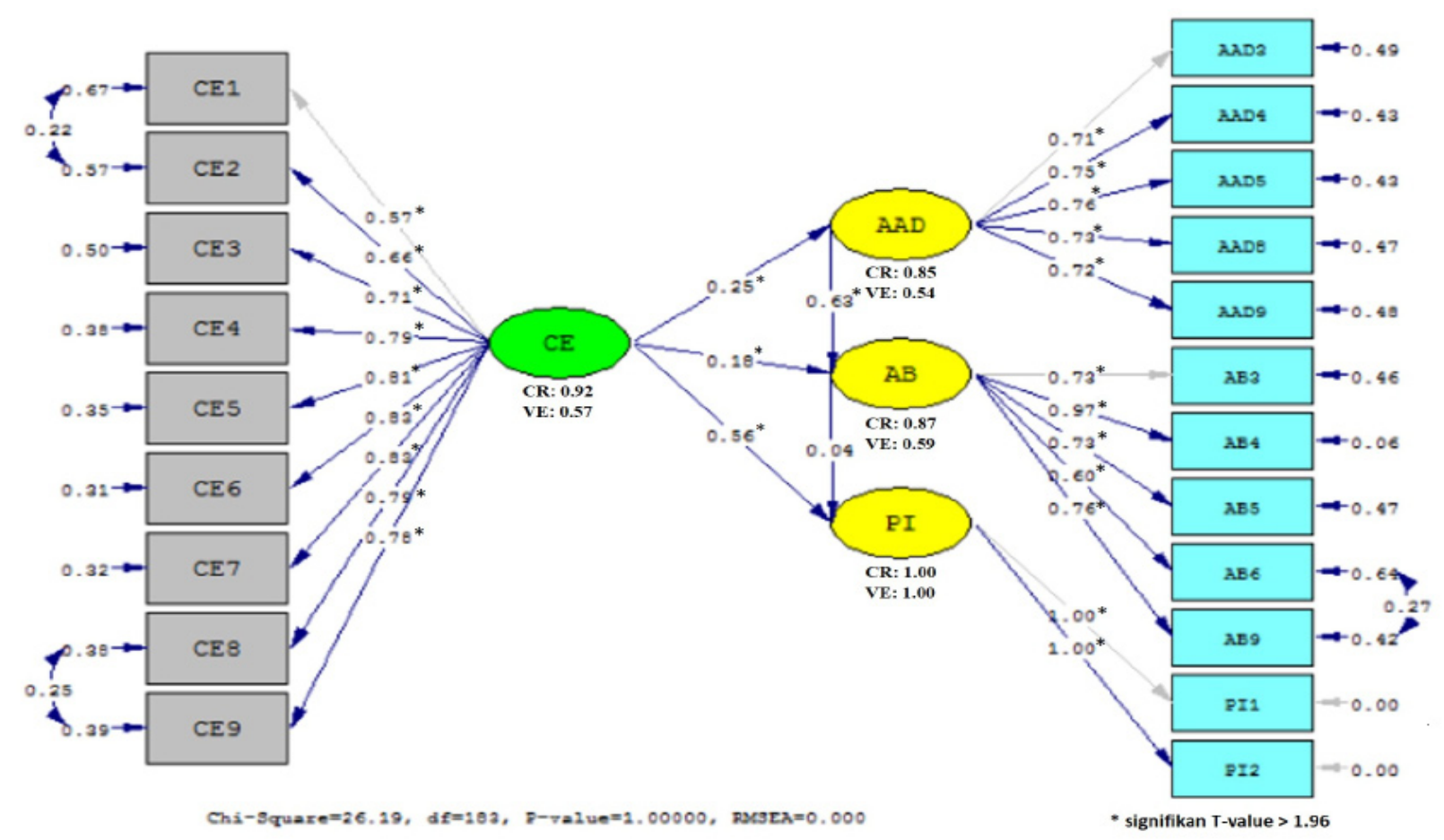

Figure 3. Structural equation modeling of Raline Shah 


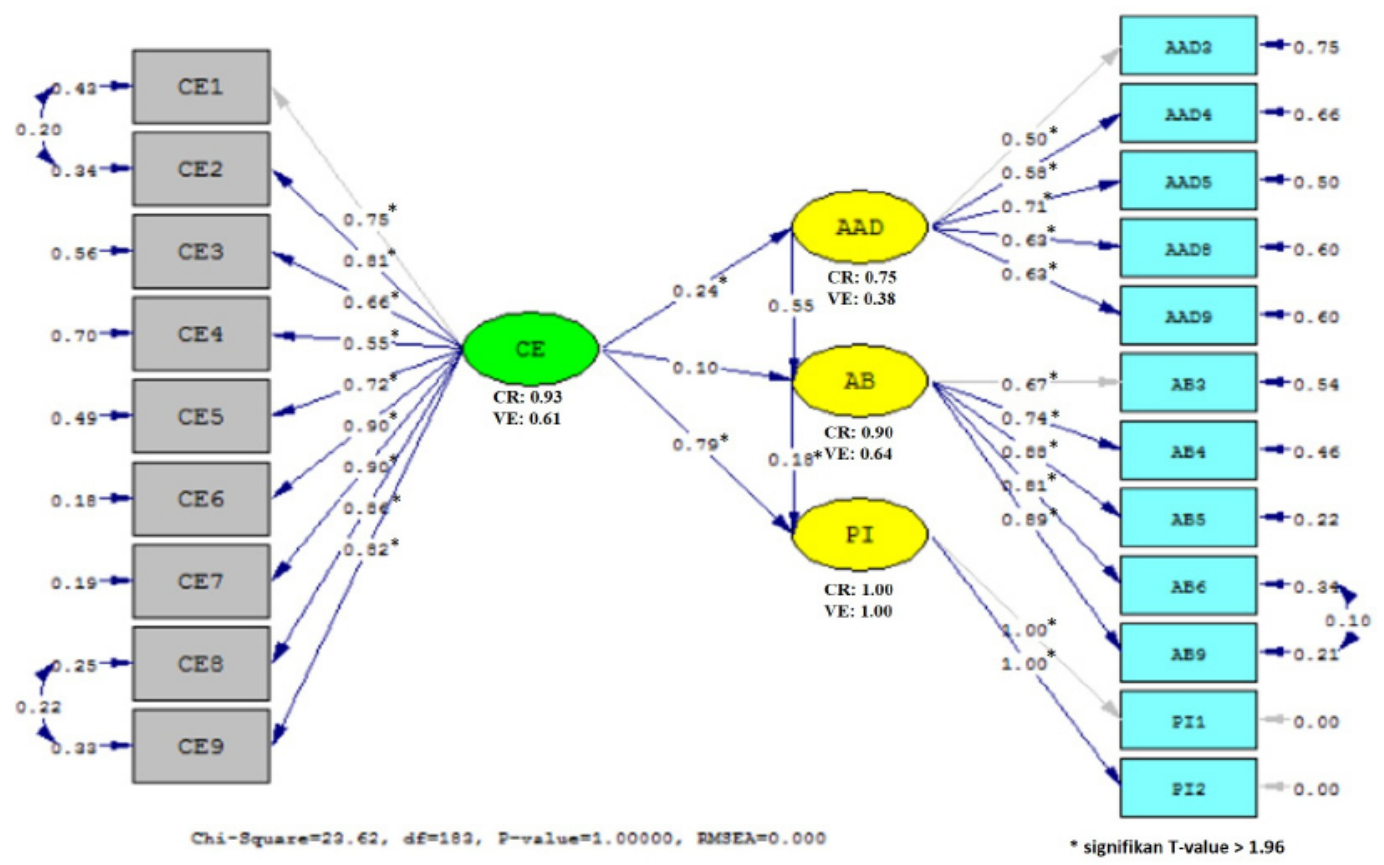

Figure 4. Structural equation modeling of Multiple Celebrity Wardah

Table 7. Standardized loading factor of celebrity credibility Wardah

\begin{tabular}{llll}
\hline Indicators & SLF (Dewi Sandra) & SLF (Raline Shah) & SLF (Multiple celebrity) \\
\hline Smart (CE1) & $0.50^{*}$ & $0.57^{*}$ & $0.75^{*}$ \\
Suitable with product (CE2) & $0.75^{*}$ & $0.66^{*}$ & $0.81^{*}$ \\
Informative (CE3) & $0.55^{*}$ & $0.71^{*}$ & $0.66^{*}$ \\
Honest (CE4) & $0.82^{*}$ & $0.79^{*}$ & $0.55^{*}$ \\
Trustworthy (CE5) & $0.82^{*}$ & $0.81^{*}$ & $0.72^{*}$ \\
Honorable (CE6) & $0.92^{*}$ & $0.83^{*}$ & $0.90^{*}$ \\
Attractive (CE7) & $0.80^{*}$ & $0.83^{*}$ & $0.90^{*}$ \\
Classy (CE8) & $0.89^{*}$ & $0.79^{*}$ & $0.86^{*}$ \\
Elegant (CE9) & $0.89^{*}$ & $0.78^{*}$ & $0.82^{*}$ \\
\hline
\end{tabular}

*) $t$ value significant at $\alpha=5 \%$

Table 8. Standardized loading factor of attitude towards Wardah's endorsement

\begin{tabular}{lccc}
\hline Indicators & SLF (Dewi Sandra) & SLF (Raline Shah) & SLF (Multiple celebrity) \\
\hline The ad was very creative (AAD3) & $0.78^{*}$ & $0.71^{*}$ & $0.50^{*}$ \\
The ad was very interesting (AAD4) & $0.71^{*}$ & $0.75^{*}$ & $0.58^{*}$ \\
The ad could be trusted (AAD5) & $0.79^{*}$ & $0.76^{*}$ & $0.71^{*}$ \\
The ad was unique/different (AAD8) & $0.80^{*}$ & $0.73^{*}$ & $0.63^{*}$ \\
The ad described quality products (AAD9) & $0.61^{*}$ & $0.72^{*}$ & $0.63^{*}$ \\
\hline
\end{tabular}

*) t value significant at $\alpha=5 \%$

Table 9. Standardized loading factor of attitude towards brand Wardah

\begin{tabular}{lccc}
\hline Indicators & SLF (Dewi Sandra) & SLF (Raline Shah) & $\begin{array}{c}\text { SLF (Multiple } \\
\text { celebrity) }\end{array}$ \\
\hline Wardah wasn't a brand that disappoint users (AB3) & $0.84^{*}$ & $0.73^{*}$ & $0.67^{*}$ \\
Wardah was a brand that can be relied upon by users (AB4) & $0.79^{*}$ & $0.97^{*}$ & $0.74^{*}$ \\
Wardah was a brand that can satisfy users (AB5) & $0.74^{*}$ & $0.73^{*}$ & $0.88^{*}$ \\
Wardah was a brand that can clean the user's facial skin & $0.68^{*}$ & $0.60^{*}$ & $0.81^{*}$ \\
(AB6) & & & $0.65^{*}$ \\
Wardah was a brand that can nourish the user's skin (AB9) & & $0.76^{*}$ & $0.89^{*}$ \\
\hline
\end{tabular}

*) t value significant at $\alpha=5 \%$ 
Looking at the loading factors of both indicators of purchase intention (Table 10), it showed that the two indicators were equally good at explaining the latent variables of purchase intention in single and multiple celebrity endorsement formats. In Wardah's endorsement starring Dewi Sandra, the consumers still needed efforts to find more detailed information about the product before finally deciding whether to buy it or not.

While celebrity credibility was seen to have a direct effect on consumer attitudes towards the Wardah brand, the relationship was only shown in the endorsement that displayed Raline Shah individually (Table 11). Consumers who perceived Raline Shah as a credible endorser for Wardah showed a direct influence on positive attitudes towards the brand, i.e. Wardah. The direct influence between these two latent variables was in line with previous studies conducted by Mitchell and Olson (1981) and Atkin and Block (1983).

When the relationship between these two latent variabels were further analyzed, it was found that there was an indirect influence between the credibility attitude and brand through mediation of attitude towards the advertisement. In Table 11, the credibility of Dewi Sandra provided indirect impact on attitude towards the brand by mediating consumer attitude towards endorsement. According to Gooldsmith et al. (2000), endorser credibility had an indirect relationship between attitude and advertisement (AAD). When consumers feel interested in an advertisement, they will form a positive attitude towards the brand displayed in the advertisement while in multiple celebrity endorsement of Wardah products, the credibility of these two celebrities did not directly and indirectly influence consumers' positive attitudes towards the brand, and this might have happened because one of the celebrities appointed as Wardah's endorsers also promoted many other brands or products. According to Lutz et al. (2012) in their research, how endorsement of a brand carried out by several celebrities was influenced by the number and other types of endorsement carried out by the celebrity. The summary of hypothesis results can be seen in Table 12 .

Table 10. Standardized loading factor of purchase intention Wardah's product

\begin{tabular}{lccc}
\hline Indicators & SLF (Dewi Sandra) & SLF (Raline Shah) & SLF (Multiple celebrity) \\
\hline $\begin{array}{l}\text { After viewing the ad, I will look for more } \\
\text { information/details about the product (PI1) }\end{array}$ & $0.99^{*}$ & $1.00^{*}$ & $1.00^{*}$ \\
$\begin{array}{l}\text { After seeing the ad, I am interested in buying the } \\
\text { product (PI2) }\end{array}$ & $0.97^{*}$ & $1.00^{*}$ & $1.00^{*}$ \\
\hline
\end{tabular}

*) $\mathrm{t}$ value significant at $\alpha=5 \%$

Table 11. Path coefficient and t-value structural equation modeling of Wardah

\begin{tabular}{|c|c|c|c|c|}
\hline Path diagram & & Dewi Sandra & Raline Shah & Multiple celebrity \\
\hline $\mathrm{H} 2: \mathrm{CE} \rightarrow \mathrm{AAD}$ & & $\begin{array}{c}0.42 \\
4.08^{*}\end{array}$ & $\begin{array}{c}0.25 \\
2.73^{*}\end{array}$ & $\begin{array}{c}0.24 \\
2.34^{*}\end{array}$ \\
\hline \multirow[t]{3}{*}{$\mathrm{H} 3: \mathrm{CE} \rightarrow \mathrm{AB}$} & & $\begin{array}{l}0.08 \\
0.84\end{array}$ & $\begin{array}{l}0.18 \\
1.98^{*}\end{array}$ & $\begin{array}{l}0.10 \\
1.01\end{array}$ \\
\hline & $\mathrm{CE} \rightarrow \mathrm{AAD} \rightarrow \mathrm{AB}$ & $\begin{array}{l}0.23 \\
2.59^{*}\end{array}$ & $\begin{array}{l}0.16 \\
2.21^{*}\end{array}$ & $\begin{array}{l}0.13 \\
1.76\end{array}$ \\
\hline & Total & $\begin{array}{c}0.31 \\
3.38^{*}\end{array}$ & $\begin{array}{c}0.33 \\
3.70^{*}\end{array}$ & $\begin{array}{l}0.23 \\
2.10^{*}\end{array}$ \\
\hline $\mathrm{H} 4: \mathrm{CE} \rightarrow \mathrm{PI}$ & & $\begin{array}{l}0.41 \\
8.07 *\end{array}$ & $\begin{array}{r}0.56 \\
8.72 *\end{array}$ & $\begin{array}{c}0.79 \\
11.05^{*}\end{array}$ \\
\hline
\end{tabular}

*) $\mathrm{t}$ value significant at $\alpha=5 \%$

Table 12. Hypothesis results of Wardah endorsement

\begin{tabular}{lllc}
\hline Hyphotesis & Dewi Sandra & Raline Shah & Multiple Celebrity \\
\hline $\mathrm{H} 2: \mathrm{CE} \rightarrow \mathrm{AAD}$ & Not rejected & Not rejected & Not rejected \\
$\mathrm{H} 3: \mathrm{CE} \rightarrow \mathrm{AB}$ & Not rejected & Not rejected & Rejected \\
$\mathrm{H} 4: \mathrm{CE} \rightarrow \mathrm{PI}$ & Not rejected & Not rejected & Not rejected \\
\hline
\end{tabular}

*) t value significant at $\alpha=5 \%$ 


\section{Managerial Implications}

Regarding the managerial implications, the results of the study provide insights and inputs for the media industry in designing promotional strategies to increase the positive attitude of consumers and their interest in buying. Companies may be able to consider choosing the best endorsement format for their brand, i.e. either single celebrity endorsement or multiple celebrity endorsement. Each format has advantages and risks which should be aware of. It is also very important for manufacturers to select credible celebrities in promoting their brands and products, and they can use the 3 credibility criteria observed in this study: trustworthiness, expertise, and physical attractiveness.

\section{CONCLUSIONS AND RECOMMENDATIONS}

\section{Conclusions}

There are no significant differences in consumer perceptions regarding celebrity credibility, attitudes towards endorsement, attitudes toward brands, and purchase intention when consumers evaluated Wardah endorsement in the formats of single celebrity endorsement and multiple celebrity endorsement. Celebrities who are considered credible by consumers could bring a positive attitude towards Wardah endorsement in both endorsement formats. The direct influence of the credibility of selected celebrities on the emergence of purchase interest are reflected in all endorsement formats.

\section{Recommendations}

The recommendations that can be given to the company is to make sure that the celebrities endorser are attractive, have good images and sufficient knowledge on the brand that is being promoted. Also, the company should ensure compatibility between celebrities and brands, and remember to monitor the images and behavior of celebrities in the public to minimize the potential impacts of negative publicity. The suggestions that can be given for further research include involving more respondents so that the results obtained are not indicative by taking examples of observations originating from different product categories such as low product involvement and high product involvement. This research was conducted from the point of view of consumers; therefore, it is interesting to carry out further research from the perspective of a company as well as of a celebrity. Celebrities are not the only ones who can be chosen as endorsers of a brand since many producers use services from endorsers outside celebrities such as athletes, celebrities, and animated figures created by a company that might provide different results from research on celebrity endorsement.

\section{REFERENCES}

Atkin C, Block M. 1983. Effectiveness of celebrity endorsers. Journal of Advertising Research 23(1):57-61.

Chavda V. 2010. A study of celebrity endorsement and its effect on buying behaviour of college students in Gujarat [dissertation]. Gujarat: Kadi Sarva Vishwavidyalaya.

Dean DH. 2001. Third Party Organization Endorsement of Products: An Advertising Cue Affecting Consumer Pre-Purchase Evaluation of Goods and Services. Journal of Advertising 30(4): 4157. https://doi.org/10.1080/00913367.2001.106 73650 .

Erdogan BZ. 1999. Celebrity endorsement: a literature review. Marketing Management 41(3): 291-314. https://doi.org/10.1362/026725799784870379.

Fornell C, Larcker DF. 1981. Evaluating structural equation models with unobservable variables and measurement error. Journal of Marketing Research 18:39-50. https://doi. org/10.1177/002224378101800104.

Goldsmith R, Lafferty B, Newell S. 2000. The impact of corporate credibility and celebrity on consumer reaction to advertisements and brands. Journal of Advertising 29(3):43-54. https://doi.org/10.1 080/00913367.2000.10673616.

Hartono JM. 2008. Pedoman Survey Kuesioner: Mengembangkan Kuesioner, Mengatasi Bias dan Meningkatkan Respon. Yogyakarta: Andi Offset.

Hsu CK, McDonaldD. 2002.Anexamination on multiple celebrity endorsers in advertising. Journal of Product \& Brand Management 11 (1): 19-29. https://doi.org/10.1108/10610420210419522.

Indrayana B, Seminar KB, Sartono B. 2016. Faktor penentu minat penggunan Instagram untuk pembelian online menggunakan tecnology acceptance model (TAM) dan theory of planned behavior (TPB). Journal Aplikasi Bisnis dan Manajemen 2(2): 138-147. https://doi. 
org/10.17358/JABM.2.2.138

Jatto O. 2014. Consumer attitude towards celebrity endorsement on social media [dissertation]. Dublin: Dublin Business School.

Lutz RJ, Rice DH, Kelting K. 2012. When exlusivity is crucial for celebrity endorsements. Journal of Consumer Psychology 22(2): 249-259. https:// doi.org/10.1016/j.jcps.2011.06.002.

Mathur LK, Rangan M. 1997. The wealth effects associated with a celebrity endorser: the Michael Jordan phenomenon. Journal of Advertising Research 37(3):67-73.

MitchellAA, OlsonJC.1981.Areproductabelieftheonly mediator of advertising effects on brand attitude. Journal of Marketing Research 18(8):318-332. https://doi.org/10.1177/002224378101800306.

Nam-Hyun U. 2008. Exploring the effects of Single vs Multiple celebrity endorsement. Journal of Management and Social Science 4: 104-114.

Ohanian R. 1990. Construction and validation of a scale to measure celebrity endorsers' perceived expertise, trustworthiness, and attractiveness. Journal of Advertising 19(3):39-52. https://doi. org/10.1080/00913367.1990.10673191.

Pughazhendi A, Ravindran DS. 2012. A study on the influence of using celebrity endorsements on consumer buying behaviour in Tamil Nadu, India. Journal of Research in International Business Management 2(4):89-96.

Raice S, Spencer AE. 2012. Insta-Rich: \$1 billion for Instagram - Facebook inks its biggest deal ever; neutralizes threat from a hot photo startup. https://www.wsj.com/articles/SB100014240 52702303815404577333840377381670 [8 Jun 2018].

Saleem F. 2007. Young adult perception towards celebrity endorsement: a comparative study of single and multiple celebrity endorsement. European Journal of Economic 8: 128-139.

Schermelleh-Engel K, Moosbrugger H, Muller H. 2003. Evaluating the fit of structural equation models: Tests of significance and descriptives goodnessof-it measures. Methods of Psychological Research Online 23-74.

Schiffman L, Kanuk LL. 2010. Consumer Behavior. 10th ed. New Jersey: Pearson Education, Inc.

Sheth BH, Solanski S. 2015. What is more effective? single celebrity verses multiple celebrity: a study on relative effectiveness of both type of print advertisement on consumer perception. International Journal of Research 3(9): 23-44.

Silvera DH, Austad B. 2004. Factors Predicting the Effectiveness of Celebrity Endorsement Advertisements. European Journal of Marketing 38: 1509-1528. https://doi. org/10.1108/03090560410560218.

$\mathrm{Wu}$ PC, Wang YC. 2011. The influences of electronic word-of-mouth message appeal and message source credibility on brand attitude. Asia Pasific Journal of Marketing and Logistics 23(4): 448-472. https://doi. org/10.1108/13555851111165020. 